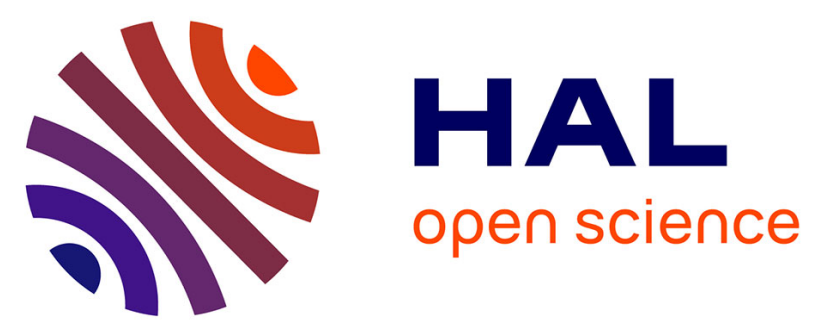

\title{
Determination of $[\mathrm{CH} 3 \mathrm{NC}] /[\mathrm{H} 2 \mathrm{C} \mathrm{C} \mathrm{NH}]$ Abundance Ratios from N + CH 3 CN Solid Phase Reaction in the Temperature Range from 10 to $40 \mathrm{~K}$ : Application to the Complex Chemistry in Star-Forming Regions
}

Lahouari Krim, Alejandro Mencos

\section{To cite this version:}

Lahouari Krim, Alejandro Mencos. Determination of $[\mathrm{CH} 3 \mathrm{NC}] /[\mathrm{H} 2 \mathrm{C} \mathrm{C} \mathrm{NH}]$ Abundance Ratios from N + CH 3 CN Solid Phase Reaction in the Temperature Range from 10 to $40 \mathrm{~K}$ : Application to the Complex Chemistry in Star-Forming Regions. ACS Earth and Space Chemistry, 2019, 3 (6), pp.973-979. 10.1021/acsearthspacechem.9b00044 . hal-02179326

\section{HAL Id: hal-02179326 \\ https: / hal.sorbonne-universite.fr/hal-02179326}

Submitted on 10 Jul 2019

HAL is a multi-disciplinary open access archive for the deposit and dissemination of scientific research documents, whether they are published or not. The documents may come from teaching and research institutions in France or abroad, or from public or private research centers.
L'archive ouverte pluridisciplinaire HAL, est destinée au dépôt et à la diffusion de documents scientifiques de niveau recherche, publiés ou non, émanant des établissements d'enseignement et de recherche français ou étrangers, des laboratoires publics ou privés. 
Determination of $\left[\mathrm{CH}_{3} \mathrm{NC}\right] /\left[\mathrm{H}_{2} \mathrm{C}=\mathrm{C}=\mathrm{NH}\right]$ abundance ratios from $\mathrm{N}+\mathrm{CH}_{3} \mathrm{CN}$ solid phase reaction in the temperature range from 10 to $40 \mathrm{~K}$ : Application to the complex chemistry in star forming regions

Lahouari $\mathrm{Krim}^{1} *$ and Alejandro Mencos ${ }^{2}$

${ }^{1}$ Sorbonne Université, CNRS, De la Molécule aux Nano-Objets: Réactivité, Interactions, Spectroscopies, MONARIS, 75005, Paris, France.

${ }^{2}$ Universidad de San Carlos de Guatemala. Ciudad Universitaria, Zona 12. Edificio T12.

Departamento de Fisicoquúmica. Guatemala.

*: Corresponding author: Lahouari.krim@upmc.fr

\section{ABSTRACT:}

The interstellar detection of $\mathrm{CH}_{3} \mathrm{CN}$ metastable isomers would suggest that $\mathrm{CH}_{3} \mathrm{NC}$ and $\mathrm{H}_{2} \mathrm{C}=\mathrm{C}=\mathrm{NH}$ formed in star forming regions through energetic processing provoked by shocks or others energy sources. In this context laboratory simulations have been carried out to investigate the chemical transformation of $\mathrm{CH}_{3} \mathrm{CN}$ into $\mathrm{CH}_{3} \mathrm{NC}_{\text {and }} \mathrm{H}_{2} \mathrm{C}=\mathrm{C}=\mathrm{NH}$ induced by UV photolysis and high energy particle irradiation. In the present study we have carried out the $\mathrm{CH}_{3} \mathrm{CN}+\mathrm{N}$ solid state reaction in the $10-40 \mathrm{~K}$ temperature range in order to examine the behavior of acetonitrile interacting with nitrogen atoms in icy interstellar grains. We show that $\mathrm{CH}_{3} \mathrm{CN}+\mathrm{N}$ is efficient in the solid phase but only in a very specific temperature range which combines high mobility and relatively long surface residence time of $\mathrm{N}$ atoms to allow the $\mathrm{CH}_{3} \mathrm{CN}$ activation. By focusing in the behavior of $\left[\mathrm{CH}_{3} \mathrm{NC}\right] /\left[\mathrm{H}_{2} \mathrm{C}=\mathrm{C}=\mathrm{NH}\right]$ abundance ratios versus temperature, we have measured abundance ratios around 10.4 at $10 \mathrm{~K}$ which decreases to 6.8 when the temperature of the reaction increases. These ratios are of the same order of magnitude as those reported from the acetonitrile isomers detection towards Sagittarius B2(N). While in previous studies involving energetic processing of solid $\mathrm{CH}_{3} \mathrm{CN}$, $\mathrm{CH}_{3} \mathrm{NC}$ and $\mathrm{CH}_{2} \mathrm{CNH}$ have been formed with $\left[\mathrm{CH}_{3} \mathrm{NC}\right] /\left[\mathrm{CH}_{2} \mathrm{CNH}\right]$ ratios ranged between 0.3 and 1.7. Additionally, the analysis of $\mathrm{CH}_{3} \mathrm{NC}$ and $\mathrm{H}_{2} \mathrm{C}=\mathrm{C}=\mathrm{NH}$ column densities shows that at low temperatures the less stable isomer is favored against the most stable one. These results are compared to the puzzling behavior of $\mathrm{CN}$-containing isomers such as $\mathrm{HNC}, \mathrm{HCN}, \mathrm{HCNO}$ and HOCN in molecular clouds.

KEYWORDS: Infrared spectroscopy, Star Forming Regions, interstellar ices, Complex organic molecules, Acetonitrile, Isocyanomethane, Ketenimine, Nitrogen atom. 


\section{INTRODUCTION}

The three $\mathrm{CN}$ bearing isomers $\mathrm{CH}_{3} \mathrm{CN}, \mathrm{CH}_{3} \mathrm{NC}$ and $\mathrm{H}_{2} \mathrm{C}=\mathrm{C}=\mathrm{NH}$ are considered as prebiotic molecules in star-forming regions and they have naturally been topics of many laboratory investigations and astronomical observations. The most stable isomer, $\mathrm{CH}_{3} \mathrm{CN}$ was the first alkyl cyanide ${ }^{1}$ detected in the interstellar medium in 1971 while its deuterated isotopologue ${ }^{2}$ $\mathrm{CDH}_{2} \mathrm{CN}$ was detected towards OMC1 hot cores in 1992 by Gerin et al. and very recently ${ }^{3}$ through Sgr B2(N2) by Belloche et al. Conversely, the two other isomers $\mathrm{CH}_{3} \mathrm{NC}$, $\mathrm{H}_{2} \mathrm{C}=\mathrm{C}=\mathrm{NH}$ seem to be less abundant in the ISM. The first tentative detection of $\mathrm{CH}_{3} \mathrm{NC}$ with an $\left[\mathrm{CH}_{3} \mathrm{CN}\right] /\left[\mathrm{CH}_{3} \mathrm{NC}\right]$ abundance ratio around 30 has been performed ${ }^{4}$ by Cernicharo et al. in 1988 toward Sgr B2(OH). More lately, $\mathrm{CH}_{3} \mathrm{NC}$ has been detected in Sgr B2(N) molecular cloud $^{5}$ and identified for the first ${ }^{6}$ time in 2018 in a solar-type protostar, IRAS 16293-2422 B with an $\left[\mathrm{CH}_{3} \mathrm{CN}\right] /\left[\mathrm{CH}_{3} \mathrm{NC}\right]$ abundance ratio of 200 . While $\mathrm{H}_{2} \mathrm{C}=\mathrm{C}=\mathrm{NH}$, which is slightly almost more stable than $\mathrm{CH}_{3} \mathrm{NC}$, has been detected by Lovas et al. toward the star-forming region $^{7}$ Sagittarius $\mathrm{B} 2(\mathrm{~N})$ hot cores with an $\left[\mathrm{CH}_{3} \mathrm{CN}\right] /\left[\mathrm{CH}_{2} \mathrm{CNH}\right]$ ratio around 100 . Lovas et al. suggested that one of the routes to form $\mathrm{H}_{2} \mathrm{C}=\mathrm{C}=\mathrm{NH}$ went through either $\mathrm{CH}_{3} \mathrm{CN}$ ionization or $\mathrm{UV}$ induced isomerization. The $\mathrm{CH}_{3} \mathrm{CN}$ ionization might occur in diffuse clouds to form $\mathrm{CH}_{3} \mathrm{CN}^{+}$which in turn would lead to $\mathrm{CH}_{2} \mathrm{CNH}^{+}$through low barrier energy of $70 \mathrm{~kJ}$ mol. The neutral $\mathrm{H}_{2} \mathrm{C}=\mathrm{C}=\mathrm{NH}$ could then be a product resulting from the $\mathrm{CH}_{2} \mathrm{CNH}^{+}+\mathrm{e}$ electron capture reaction. While the $\mathrm{UV}$ induced $\mathrm{CH}_{3} \mathrm{CN} \rightarrow \mathrm{H}_{2} \mathrm{C}=\mathrm{C}=\mathrm{NH}$ tautomerization which shows an energy barrier ${ }^{8}$ of $370 \mathrm{~kJ} / \mathrm{mol}$ would be more probable in the SgrB2(N) region which contains widespread shocks to provide enough energy to the reaction to occur. However, these two reaction pathways leading to the formation of $\mathrm{H}_{2} \mathrm{C}=\mathrm{C}=\mathrm{NH}$ from its more abundant isomer $\mathrm{CH}_{3} \mathrm{CN}$ exclude all the processes which may occur in dark regions not exposed to external energy sources. Additionally, $\mathrm{CH}_{3} \mathrm{CN}$ has been also detected in comets, in atmospheres of moons and planets ${ }^{9-15}$, but no trace of $\mathrm{H}_{2} \mathrm{C}=\mathrm{C}=\mathrm{NH}$ and $\mathrm{CH}_{3} \mathrm{NC}$ which may also be present with a kind of $\left[\mathrm{CH}_{3} \mathrm{CN}\right] /\left[\mathrm{H}_{2} \mathrm{C}=\mathrm{C}=\mathrm{NH}\right] /\left[\mathrm{CH}_{3} \mathrm{NC}\right]$ abundance ratios which may inform about the existing links between these three isomers. In order to answer the question how $\mathrm{CH}_{3} \mathrm{CN}, \mathrm{CH}_{3} \mathrm{NC}, \mathrm{H}_{2} \mathrm{C}=\mathrm{C}=\mathrm{NH}$ form and how they evolve in space, many groups have investigated reactions involving $\mathrm{CH}_{3} \mathrm{CN}$ as precursor through energetic processing to mimic the chemistry involved in the ISM and atmospheres of moons and planets. As reactions occurring in solid phase at cryogenic temperatures are known to be one of the main sources of the chemical complexity of the Universe, many laboratory studies have been focused in solid state reactions on interstellar, cometary and atmospheric ice analogues in the $10-200 \mathrm{~K}$ 
temperature range. In this context, Hudson et al. have already shown that the bombardment ${ }^{16}$ by $0.8 \mathrm{MeV} \mathrm{H}^{+}$ion of $\mathrm{CH}_{3} \mathrm{CN}$ ices formed at $10 \mathrm{~K}$ led to $\mathrm{CH}_{3} \mathrm{NC}, \mathrm{H}_{2} \mathrm{CCNH}, \mathrm{HCN}$, and $\mathrm{CH}_{4}$. Similarly, Abdulgalil et al. showed that the irradiation ${ }^{17}$ of $\mathrm{CH}_{3} \mathrm{CN}$ ices by $200 \mathrm{keV} \mathrm{\textrm {H } ^ { + }}$ particles formed $\mathrm{CH}_{3} \mathrm{NC}, \mathrm{H}_{2} \mathrm{CCNH}, \mathrm{HCN}, \mathrm{HCCCN}$ and $\mathrm{CH}_{4}$. These two studies have shown the chemical transformation of $\mathrm{CH}_{3} \mathrm{CN}$ into $\mathrm{CH}_{3} \mathrm{NC}$ and $\mathrm{H}_{2} \mathrm{C}=\mathrm{C}=\mathrm{NH}$ through energetic processing in solid phase to prove that $\mathrm{CH}_{3} \mathrm{CN}$ isomerization would take place only in regions of space containing shocks or other energy sources. However, in order to examine the behavior of $\mathrm{CH}_{3} \mathrm{CN}$ interacting with particles less energetic than $0.8 \mathrm{MeV} \mathrm{H}^{+}$ion or $200 \mathrm{keV}$ $\mathrm{H}^{+}$, we have recently investigated ${ }^{18}$ the $\mathrm{CH}_{3} \mathrm{CN}+\mathrm{N}$ solid state reaction in the $3-10 \mathrm{~K}$ temperature range to underline the role of the nitrogen atoms in icy interstellar grains. Our study showed for the first time that by monitoring the mobility of ground state nitrogen atoms between 3 and $10 \mathrm{~K}$, we form $\mathrm{N}_{2}{ }^{*}$ long lived metastable species known as $\mathrm{N}_{2}(\mathrm{~A})$ excited molecular nitrogen which while interacting with $\mathrm{CH}_{3} \mathrm{CN}$ induced its isomerization into $\mathrm{CH}_{3} \mathrm{NC}$ and $\mathrm{CH}_{2} \mathrm{CNH}$ through energy transfer process as follows:

$\mathrm{N}+\mathrm{N} \rightarrow \mathrm{N}_{2} *$

$\mathrm{N}_{2} *+\mathrm{CH}_{3} \mathrm{CN} \rightarrow \mathrm{N}_{2}+\mathrm{CH}_{3} \mathrm{CN}^{*} \rightarrow \mathrm{N}_{2}+\mathrm{CH}_{3} \mathrm{NC}$ or $\mathrm{CH}_{2} \mathrm{CNH}$

In the context of the present work we have studied the influence of the temperature on the $\mathrm{CH}_{3} \mathrm{CN}+\mathrm{N}$ solid state reaction from 10 to $40 \mathrm{~K}$, a temperature range relevant to star forming regions, by focusing in the evolution of $\left[\mathrm{CH}_{3} \mathrm{CN}\right] /\left[\mathrm{H}_{2} \mathrm{C}=\mathrm{C}=\mathrm{NH}\right] /\left[\mathrm{CH}_{3} \mathrm{NC}\right]$ abundance ratios versus temperature and also versus the environment where these three isomers are formed.

\section{EXPERIMENTAL METHODS}

Molecular nitrogen has been purchased from Messer, with a purity of $99.9995 \%$. Natural $\mathrm{CH}_{3} \mathrm{CN}$, purchased from Sigma-Aldrich with a purity of $99.9 \%$ was degassed under vacuum. Our samples were prepared under ultrahigh vacuum of $10^{-10}$ mbar by co-depositing pure $\mathrm{CH}_{3} \mathrm{CN}$ and $\mathrm{N} / \mathrm{N}_{2}$ mixture on a Rh-plated copper mirror maintained at temperatures ranged between 10 and $40 \mathrm{~K}$, using a closed-cycle helium cryogenerator (Sumitomo cryogenics F70). The $\mathrm{N}$ atoms were generated with a flux of about $10^{15}$ atoms $\mathrm{cm}^{-2} \mathrm{~s}^{-1}$ using a microwave discharge (SPECS, PCS-ECR) into $\mathrm{N}_{2}$ gas. We have measured the yield dissociation of $\mathrm{N}_{2}$ molecules around $4 \%$, using a Quadrupole Mass Spectrometer (QMS - Hidden Analytical). Samples were analyzed using Bruker Vertex 80v Fourier infrared (FTIR) spectrometer in 
transmission-reflection mode, between 5000 and $500 \mathrm{~cm}^{-1}$ with a spectral resolution of 0.5 $\mathrm{cm}^{-1}$. The sample holder, consisting of six mirrors optically polished mounted on a hexagonal face copper block which allows as mentioned earlier the simultaneous study of the $\mathrm{CH}_{3} \mathrm{CN}+$ $\mathrm{N}$ reaction by two methods of $\mathrm{CH}_{3} \mathrm{CN}+\mathrm{N} / \mathrm{N}_{2}$ ice co-depositions as shown in figure 1 .

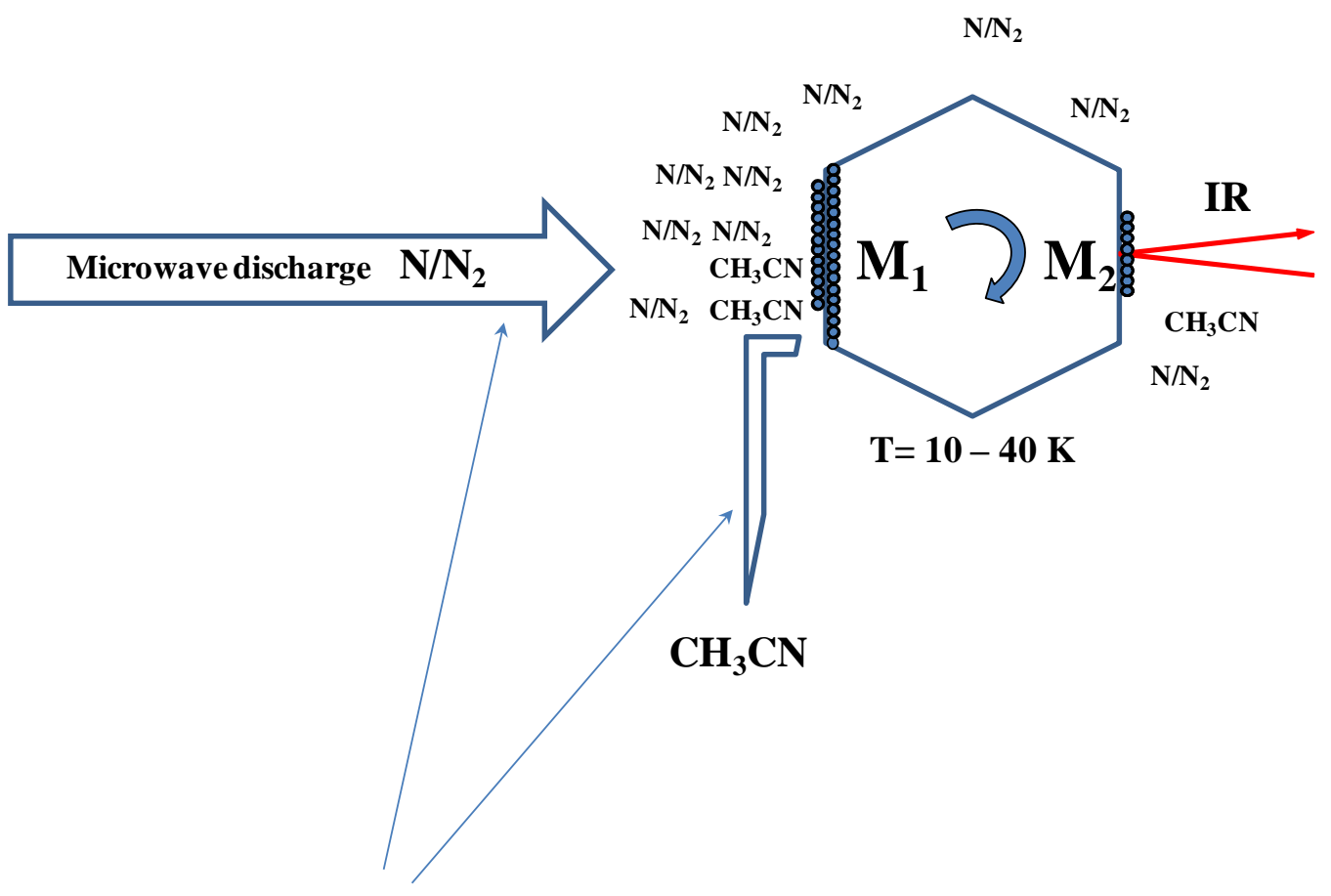

$\mathrm{CH}_{3} \mathrm{CN}$ and $\mathrm{N} / \mathrm{N}_{2}$ injection ports

Figure 1: Direct and indirect $\mathrm{CH}_{3} \mathrm{CN}+\mathrm{N} / \mathrm{N}_{2}$ co-deposition on mirror $\mathrm{M} 1$ and $\mathrm{M} 2$, respectively.

a/ Direct deposition: It consists of forming icy samples through a direct co-injection of the reactants $\mathrm{CH}_{3} \mathrm{CN}+\mathrm{N} / \mathrm{N}_{2}$ on the surface of a cryogenic mirror located just front of the injection ports. Pure $\mathrm{CH}_{3} \mathrm{CN}$ vapor gas was injected into the high vacuum chamber at a pressure of $10^{-8}$ mbar. Simultaneously, $\mathrm{N} / \mathrm{N}_{2}$ mixture generated from the microwave discharge was injected at a pressure of $10^{-5}$ mbar. The $\mathrm{CH}_{3} \mathrm{CN}+\mathrm{N} / \mathrm{N}_{2}$ co-deposition lasted 30 minutes. This co-injection method is a traditional one used by many groups to study solid sate reactions at cryogenic temperatures. With such a method, the icy samples are mainly made of reactants with high abundances, including a few amounts of the reaction products which depend in the efficiency of the reaction during the sample deposition. Additionally, using spectroscopy ground methods to probe the solid samples results in an overlapping between the huge signals due to the reactants with those due to the reaction products, generally very low. 
b/ Indirect deposition: It is a background dosing which consists of forming icy samples through simultaneous condensation of $\mathrm{CH}_{3} \mathrm{CN}+\mathrm{N} / \mathrm{N}_{2}$ mixture gas suspended in the vacuum chamber. As, the condensation of the species $\left(\mathrm{CH}_{3} \mathrm{CN}, \mathrm{N}, \mathrm{N}_{2}\right)$ suspended in the vacuum chamber depends on their masses $\left(\mathrm{M}_{\mathrm{CH} 3 \mathrm{CN}}>\mathrm{M}_{\mathrm{N} 2}>\mathrm{M}_{\mathrm{N}}\right)$ the solid samples should contain more $\mathrm{N}$ atoms than $\mathrm{N}_{2}$ and $\mathrm{CH}_{3} \mathrm{CN}$ molecules. We have managed using this method, as it will be discussed bellow, to create icy samples containing amounts of reaction products twice higher than those of the reactants.

\section{RESULTS AND DISCUSSIONS}

In order to characterize the $\mathrm{CH}_{3} \mathrm{CN}+\mathrm{N}$ reaction in the 10-40 $\mathrm{K}$ temperature range, figure 2 shows the IR spectra resulting from the co-injections of $\mathrm{CH}_{3} \mathrm{CN}+\mathrm{N}_{2}$ and $\mathrm{CH}_{3} \mathrm{CN}+\mathrm{N} / \mathrm{N}_{2}$, respectively, carried out at $20 \mathrm{~K}$. The assignments of all vibrational modes ${ }^{19}$ of $\mathrm{CH}_{3} \mathrm{CN}$ ice are directly reported in spectrum $2 \mathrm{~b}$. The comparison between the two IR spectra permits discrimination of the IR signals derived from $\mathrm{CH}_{3} \mathrm{CN}+\mathrm{N}$ reaction products. We notice that the only new IR signals clearly visible and not hidden by those of the reactants and which would be assigned to the $\mathrm{CH}_{3} \mathrm{CN}+\mathrm{N}$ reaction products are located in the $2200-1900 \mathrm{~cm}^{-1}$ spectral region. 


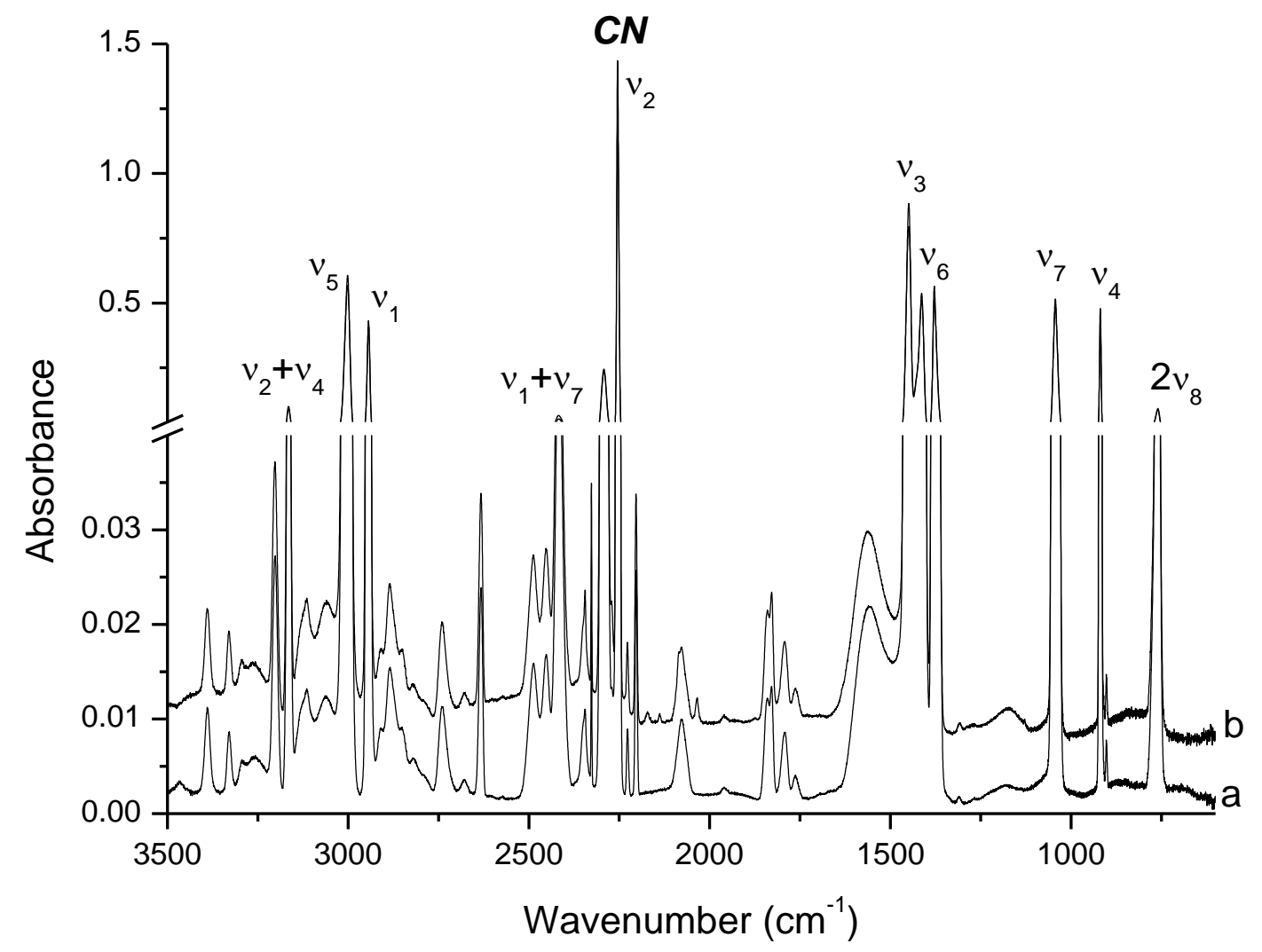

Figure 2: $\mathrm{CH}_{3} \mathrm{CN}+\mathrm{N}$ solid sate reaction at $20 \mathrm{~K}$. a) $\mathrm{CH}_{3} \mathrm{CN}+\mathrm{N}_{2}$ co-deposition. b) $\mathrm{CH}_{3} \mathrm{CN}+$ $\mathrm{N} / \mathrm{N}_{2}$ co-deposition.

The expansion of spectra $2 \mathrm{a}$ and $2 \mathrm{~b}$ in $2200-1840 \mathrm{~cm}^{-1}$ spectral region are shown in figure 3 where new IR signals related to $\mathrm{CH}_{3} \mathrm{CN}+\mathrm{N}$ solid sate reaction carried out at $20 \mathrm{~K}$ are observed at 2038, 2086 and $2167 \mathrm{~cm}^{-1}$ and which have been assigned to $\mathrm{CH}_{2} \mathrm{CNH}, \mathrm{CN}^{-}$and $\mathrm{CH}_{3} \mathrm{NC}$ reaction products, respectively. We have already discussed these IR signal attributions in a previous study performed in the 3-10 $\mathrm{K}$ temperature range, showing that atomic nitrogen interacting with acetonitrile leads to the formation of $\mathrm{CH}_{3} \mathrm{NC}, \mathrm{CH}_{2} \mathrm{CNH}$ and $\mathrm{CN}^{-}$. These reactions products are similar to those obtained through energetic particle irradiation of $\mathrm{CH}_{3} \mathrm{CN}$ ices. In the present study, we will focus only in the three $\mathrm{CH}_{3} \mathrm{CN}$, $\mathrm{H}_{2} \mathrm{C}=\mathrm{C}=\mathrm{NH}, \mathrm{CH}_{3} \mathrm{NC}$ isomers. The main conclusion of our previous study, is that although the $\mathrm{CH}_{3} \mathrm{CN}+\mathrm{N}\left({ }^{4} \mathrm{~S}\right)$ reaction taken in the ground state is endothermic and would need an energy supply to occur, it takes place in solid phase because $\mathrm{N}\left({ }^{4} \mathrm{~S}\right)-\mathrm{N}\left({ }^{4} \mathrm{~S}\right)$ recombination is more favourable in the solid state than in the gas phase. The $N\left({ }^{4} \mathrm{~S}\right)-\mathrm{N}\left({ }^{4} \mathrm{~S}\right)$ recombination is an exothermic process leading either to $945.6 \mathrm{~kJ} / \mathrm{mol}$ energy release or to the formation of a reactive metastable molecular nitrogen $\mathrm{N}_{2}(\mathrm{~A})$ which contains $665.7 \mathrm{~kJ} / \mathrm{mol}$ of energy ${ }^{20,21}$. The 
solid phase formation of such a long-lived metastable ${ }^{22,23}$ allows $\mathrm{CH}_{3} \mathrm{CN}$ isomerisation into $\mathrm{CH}_{3} \mathrm{NC}$ and $\mathrm{CH}_{2} \mathrm{CNH}$ through $\mathrm{N}_{2}(\mathrm{~A}) \leftrightarrow \mathrm{CH}_{3} \mathrm{CN}$ energy transfer. It is important to notice that the two reaction pathways ${ }^{8}$ leading to $\mathrm{CH}_{3} \mathrm{NC}$ and $\mathrm{CH}_{2} \mathrm{CNH}$ from $\mathrm{CH}_{3} \mathrm{CN}$ are endothermic by 97.5 and $91.5 \mathrm{~kJ} / \mathrm{mol}$, respectively and have 261.5 and $368.6 \mathrm{~kJ} / \mathrm{mol}$ as energy barriers, respectively. Even though $\mathrm{CH}_{2} \mathrm{CNH}$ is slightly more stable by $6 \mathrm{~kJ} / \mathrm{mol}$ than $\mathrm{CH}_{3} \mathrm{NC}$, it shows the highest barrier in the $\mathrm{CH}_{3} \mathrm{CN}$ isomerization reaction and consequently among the three isomers it should be the less abundant.

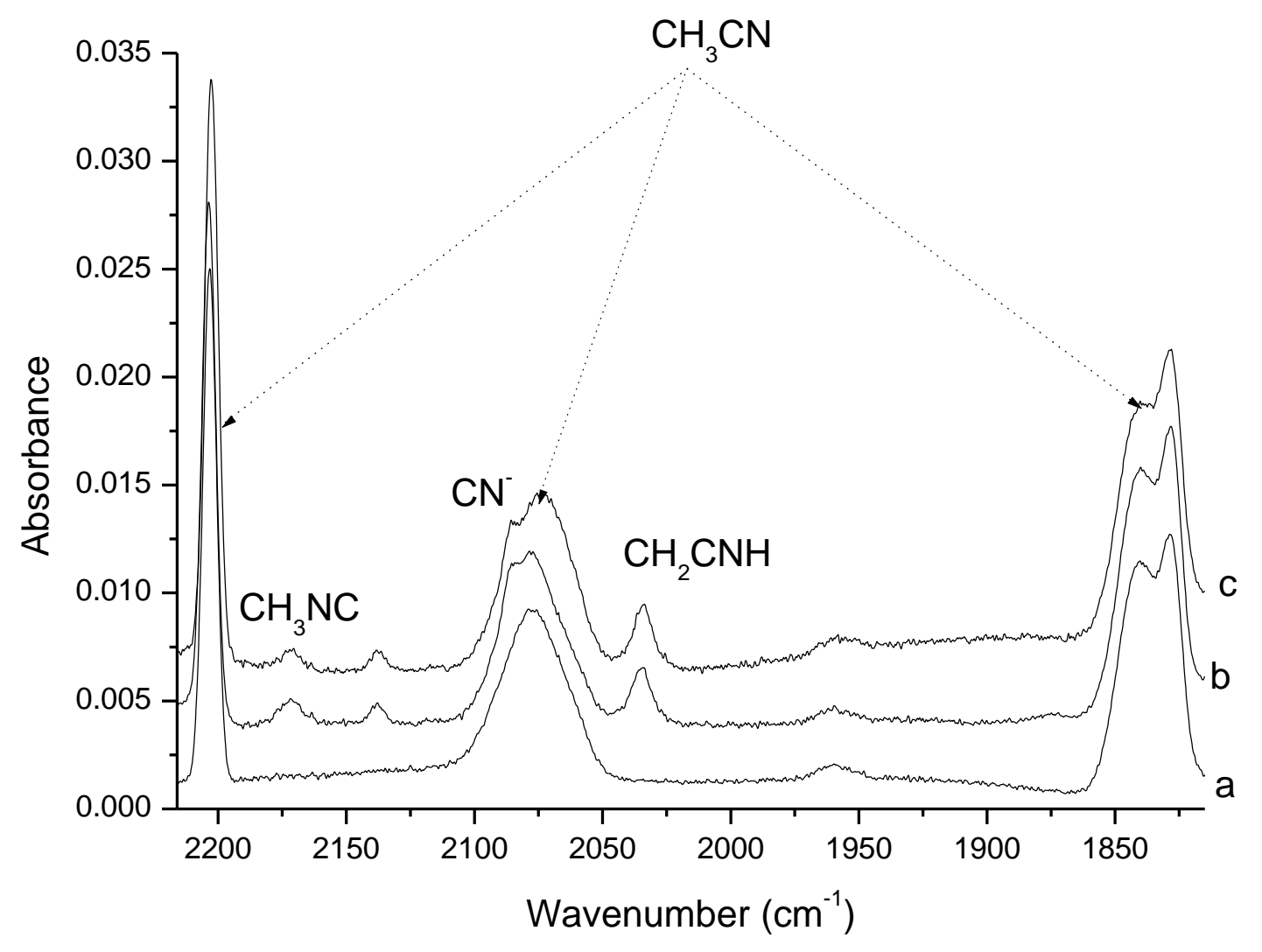

Figure 3: Zoom of figure 1 in 2200-1840 $\mathrm{cm}^{-1}$ spectral region. a) $\mathrm{CH}_{3} \mathrm{CN}+\mathrm{N}_{2}$ co-deposition at $20 \mathrm{~K}$. b) $\mathrm{CH}_{3} \mathrm{CN}+\mathrm{N} / \mathrm{N}_{2}$ co-deposition at $20 \mathrm{~K}$. c) $\mathrm{CH}_{3} \mathrm{CN}+\mathrm{N} / \mathrm{N}_{2}$ co-deposition at $20 \mathrm{~K}$, followed by a sample heating to $40 \mathrm{~K}$. The band at $2138 \mathrm{~cm}^{-1}$ is due to $\mathrm{CO}$ molecule, a sample impurity usually detected in experiments using atom-bombardment.

The goal of the present work is to investigate the behavior of $\mathrm{CH}_{3} \mathrm{CN}+\mathrm{N}\left({ }^{4} \mathrm{~S}\right)$ solid state reaction between 10 and $40 \mathrm{~K}$ where the $\mathrm{N}\left({ }^{4} \mathrm{~S}\right)-\mathrm{N}\left({ }^{4} \mathrm{~S}\right)$ recombination would be much more efficient than in the 3-10 K temperature range. Spectrum $3 \mathrm{c}$ shows the results of $\mathrm{CH}_{3} \mathrm{CN}+$ 
$\mathrm{N} / \mathrm{N}_{2}$ co-deposition at $20 \mathrm{~K}$, followed by a sample heating to $40 \mathrm{~K}$. We notice, by comparing spectra $3 \mathrm{~b}$ and $3 \mathrm{c}$, that the intensities of the IR signals of the reaction products do not change after sample heating to $40 \mathrm{~K}$. There is then no reaction taking place during the sample heating from 20 to $40 \mathrm{~K}$ and this could be linked to the amount of $\mathrm{N}$-atoms in the $\mathrm{CH}_{3} \mathrm{CN}+\mathrm{N} / \mathrm{N}_{2}$ ices formed at $20 \mathrm{~K}$. As at $20 \mathrm{~K}$ the mobility of $\mathrm{N}$-atoms is very efficient ${ }^{24}$, the $\mathrm{CH}_{3} \mathrm{CN}+\mathrm{N}$ reaction occurring during the sample deposition is totally complete. As all $\mathrm{N}$-atoms have already recombined during the sample deposition, there are no more nitrogen atoms left in a sample prepared at $20 \mathrm{~K}$ and consequently, the sample heating from 20 to $40 \mathrm{~K}$ cannot induce the $\mathrm{N}\left({ }^{4} \mathrm{~S}\right)-\mathrm{N}\left({ }^{4} \mathrm{~S}\right)$ recombination essential for the chemical transformation of $\mathrm{CH}_{3} \mathrm{CN}$ in the solid phase.

The $\mathrm{CH}_{3} \mathrm{CN}+\mathrm{N}_{2} / \mathrm{N}$ co-deposition carried out at $10 \mathrm{~K}$, followed by a sample heating to $40 \mathrm{~K}$ is shown in figure 4 . We note that the IR signals of the reaction products due to $\mathrm{CH}_{3} \mathrm{CN}$ interacting with $\mathrm{N}$-atoms, namely $\mathrm{CH}_{3} \mathrm{NC}, \mathrm{CH}_{2} \mathrm{CNH}$, and $\mathrm{CN}^{-}$are present in the IR spectrum recorded just after the sample deposition at $10 \mathrm{~K}$ (spectrum $4 \mathrm{a}$ ). This proves that at $10 \mathrm{~K}$, the mobility of the $\mathrm{N}$-atoms is efficient enough to provoke $\mathrm{N}\left({ }^{4} \mathrm{~S}\right)-\mathrm{N}\left({ }^{4} \mathrm{~S}\right)$ recombination and to allow the $\mathrm{CH}_{3} \mathrm{CN}+\mathrm{N}$ reaction to partially occur during the $\mathrm{CH}_{3} \mathrm{CN}+\mathrm{N} / \mathrm{N}_{2}$ co-deposition. As shown in spectrum $4 \mathrm{~b}$, counter to the $\mathrm{CH}_{3} \mathrm{CN}+\mathrm{N} / \mathrm{N}_{2}$ co-deposition carried out at $20 \mathrm{~K}$, the heating of the sample formed at $10 \mathrm{~K}$, to $40 \mathrm{~K}$ leads to an increase of the IR signals of the reaction products. Thus, just after the sample deposition at $10 \mathrm{~K}$, there are still free $\mathrm{N}$-atoms trapped in the mixed $\mathrm{CH}_{3} \mathrm{CN}-\mathrm{N}_{2}$ ice which start recombining and transforming $\mathrm{CH}_{3} \mathrm{CN}$ when the temperature of sample increases. However, comparison between spectra $4 \mathrm{a}$ and $4 \mathrm{~b}$ shows that the IR signals of $\mathrm{CH}_{3} \mathrm{NC}$ and $\mathrm{CH}_{2} \mathrm{CNH}$ behave differently when the temperature of the sample increases. The heating of the sample from 10 to $40 \mathrm{~K}$ shows that the absorption band areas of $\mathrm{CH}_{3} \mathrm{NC}$ and $\mathrm{CH}_{2} \mathrm{CNH}$ increase from 0.005 to $0.010 \mathrm{~cm}^{-1}$ and from 0.016 to $0.049 \mathrm{~cm}^{-}$ 1 , respectively. In the $\mathrm{N}_{2}(\mathrm{~A})+\mathrm{CH}_{3} \mathrm{CN} \rightarrow \mathrm{N}_{2}+\mathrm{CH}_{3} \mathrm{CN}^{*} \rightarrow \mathrm{N}_{2}+\mathrm{CH}_{3} \mathrm{NC}$ or $\mathrm{CH}_{2} \mathrm{CNH}$ processing, $\mathrm{CH}_{2} \mathrm{CNH}$ the isomer with the highest energy barrier forms more efficiently in the solid phase during sample heating from 10 to $40 \mathrm{~K}$. Converted into column densities (molecules $\mathrm{cm}^{-2}$ ) by taking the band strengths ${ }^{25}$ of $\mathrm{CH}_{2} \mathrm{CNH}, \mathrm{A}(=\mathrm{C}=\mathrm{NH})$ and organic nitriles $\mathrm{CH}_{3} \mathrm{CN}$ and $\mathrm{CH}_{3} \mathrm{NC}, \mathrm{A}(\mathrm{C} \equiv \mathrm{N})$ around $7.2 \times 10^{-17}$ and $2.2 \times 10^{-18} \mathrm{~cm}$ molecule $\mathrm{e}^{-1}$, respectively, calculations of integrated intensities of the $\mathrm{CN}$ absorption bands show that the heating of the sample from 10 to $40 \mathrm{~K}$ leads to an increase of $\mathrm{CH}_{3} \mathrm{NC}$ and $\mathrm{CH}_{2} \mathrm{CNH}$ from $2.3 \times 10^{15}$ to $4.6 \times 10^{15}$ and from $2.2 \times 10^{14}$ to $6.8 \times 10^{14}$ molecule $\mathrm{cm}^{-2}$, respectively. Taking absorption band area measurement uncertainties into account, we measure an $\left[\mathrm{CH}_{3} \mathrm{NC}\right] /\left[\mathrm{CH}_{2} \mathrm{CNH}\right]$ abundance 
ratio of $10.4 \pm 1.2$ just after the $\mathrm{CH}_{3} \mathrm{CN}+\mathrm{N} / \mathrm{N}_{2}$ sample deposition at $10 \mathrm{~K}$. While the heating of the sample from 10 to $40 \mathrm{~K}$ leads to an $\left[\mathrm{CH}_{3} \mathrm{NC}\right] /\left[\mathrm{CH}_{2} \mathrm{CNH}\right]$ ratio of $6.8 \pm 0.8$, showing that even though we form more of $\mathrm{CH}_{3} \mathrm{NC}$ than $\mathrm{CH}_{2} \mathrm{CNH}$ through $\mathrm{CH}_{3} \mathrm{CN}+\mathrm{N}$ solid state reaction, $\mathrm{CH}_{2} \mathrm{CNH}$ formation becomes more favorable than that of $\mathrm{CH}_{3} \mathrm{NC}$ during the sample heating.

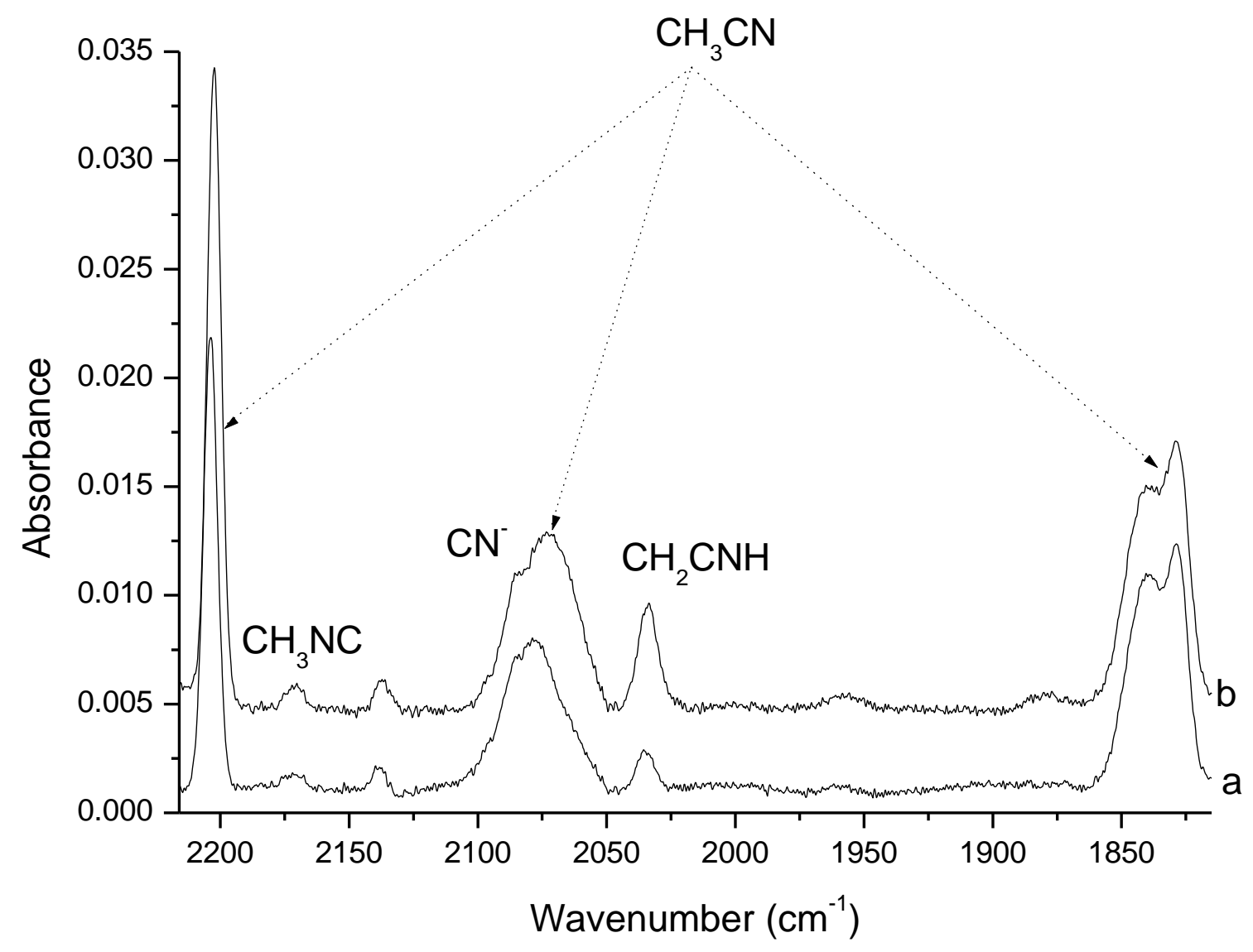

Figure 4: a) $\mathrm{CH}_{3} \mathrm{CN}+\mathrm{N} / \mathrm{N}_{2}$ co-deposition at $10 \mathrm{~K}$. b) $\mathrm{CH}_{3} \mathrm{CN}+\mathrm{N} / \mathrm{N}_{2}$ co-deposition at $10 \mathrm{~K}$ and sample heating to $40 \mathrm{~K}$.

From these two experimental results related to sample depositions at 10 and $20 \mathrm{~K}$ followed by sample heating to $40 \mathrm{~K}$, we show that the $\mathrm{CH}_{3} \mathrm{CN}+\mathrm{N}$ reaction is temperature dependent. The reaction is complete with a $\mathrm{CH}_{3} \mathrm{CN}+\mathrm{N} / \mathrm{N}_{2}$ co-deposition carried out at $20 \mathrm{~K}$ as the $\mathrm{N}$-atoms are used up during the sample formation. At $10 \mathrm{~K}$, the reaction is not complete and keeps occurring in solid phase during the heating of the sample between 10 and $40 \mathrm{~K}$ to stimulate the $\mathrm{N}\left({ }^{4} \mathrm{~S}\right)-\mathrm{N}\left({ }^{4} \mathrm{~S}\right)$ recombination and to form $\mathrm{N}_{2}(\mathrm{~A})$ reactive metastable which induces the chemical transformation of $\mathrm{CH}_{3} \mathrm{CN}$. However nitrogen molecules desorb ${ }^{26}$ at $26 \mathrm{~K}$ and as the 
$\mathrm{CH}_{3} \mathrm{CN}+\mathrm{N}$ seems to depend in the formation of $\mathrm{N}_{2}(\mathrm{~A})$ reaction intermediate which also desorbs at $26 \mathrm{~K}$, we have investigated a $\mathrm{CH}_{3} \mathrm{CN}+\mathrm{N} / \mathrm{N}_{2}$ co-injection at temperature higher than $26 \mathrm{~K}$ to avoid condensation of $\mathrm{N}_{2}$ during the sample deposition. Spectra $5 \mathrm{a}, 5 \mathrm{~b}$ and $5 \mathrm{c}$ show a comparative study of $\mathrm{CH}_{3} \mathrm{CN}+\mathrm{N} / \mathrm{N}_{2}$ co-injections at 10,20 and $40 \mathrm{~K}$, respectively. We notice that the $\mathrm{CH}_{3} \mathrm{NC}, \mathrm{CH}_{2} \mathrm{CNH}$, and $\mathrm{CN}^{-}$reaction products derived from $\mathrm{CH}_{3} \mathrm{CN}+\mathrm{N}$ solid state reaction are formed at 10 and $20 \mathrm{~K}$ but not at $40 \mathrm{~K}$.

Consequently, even though a temperature of $40 \mathrm{~K}$ is high enough to increase the mobility of nitrogen atoms in the sample and to enhance the $\mathrm{N}\left({ }^{4} \mathrm{~S}\right)-\mathrm{N}\left({ }^{4} \mathrm{~S}\right)$ recombination, it does not lead to the chemical transformation of $\mathrm{CH}_{3} \mathrm{CN}$ when the reactants are co-deposited at $40 \mathrm{~K}$. This proves that in order to be efficient in solid phase, the $\mathrm{CH}_{3} \mathrm{CN}+\mathrm{N}$ reaction needs the $\mathrm{N}_{2}(\mathrm{~A})$ reaction intermediate with a surface residence time long enough to allow the $\mathrm{N}_{2}(\mathrm{~A}) \leftrightarrow$ $\mathrm{CH}_{3} \mathrm{CN}$ energy transfer. While at $40 \mathrm{~K}$, the residence time of $\mathrm{N}$ atoms on the surface is too short to even allow the $\mathrm{N}\left({ }^{4} \mathrm{~S}\right)-\mathrm{N}\left({ }^{4} \mathrm{~S}\right)$ recombination. By varying the reaction temperature between 10 and $40 \mathrm{~K}$, we give thus an upper limit for the solid state reactivity of atomic nitrogen which would be efficient only in a specific temperature range combining long residence time and high mobility of $\mathrm{N}$-atoms to induce $\mathrm{N}\left({ }^{4} \mathrm{~S}\right)-\mathrm{N}\left({ }^{4} \mathrm{~S}\right)$ recombination and then $\mathrm{N}_{2}(\mathrm{~A})$ reaction intermediate formation. 


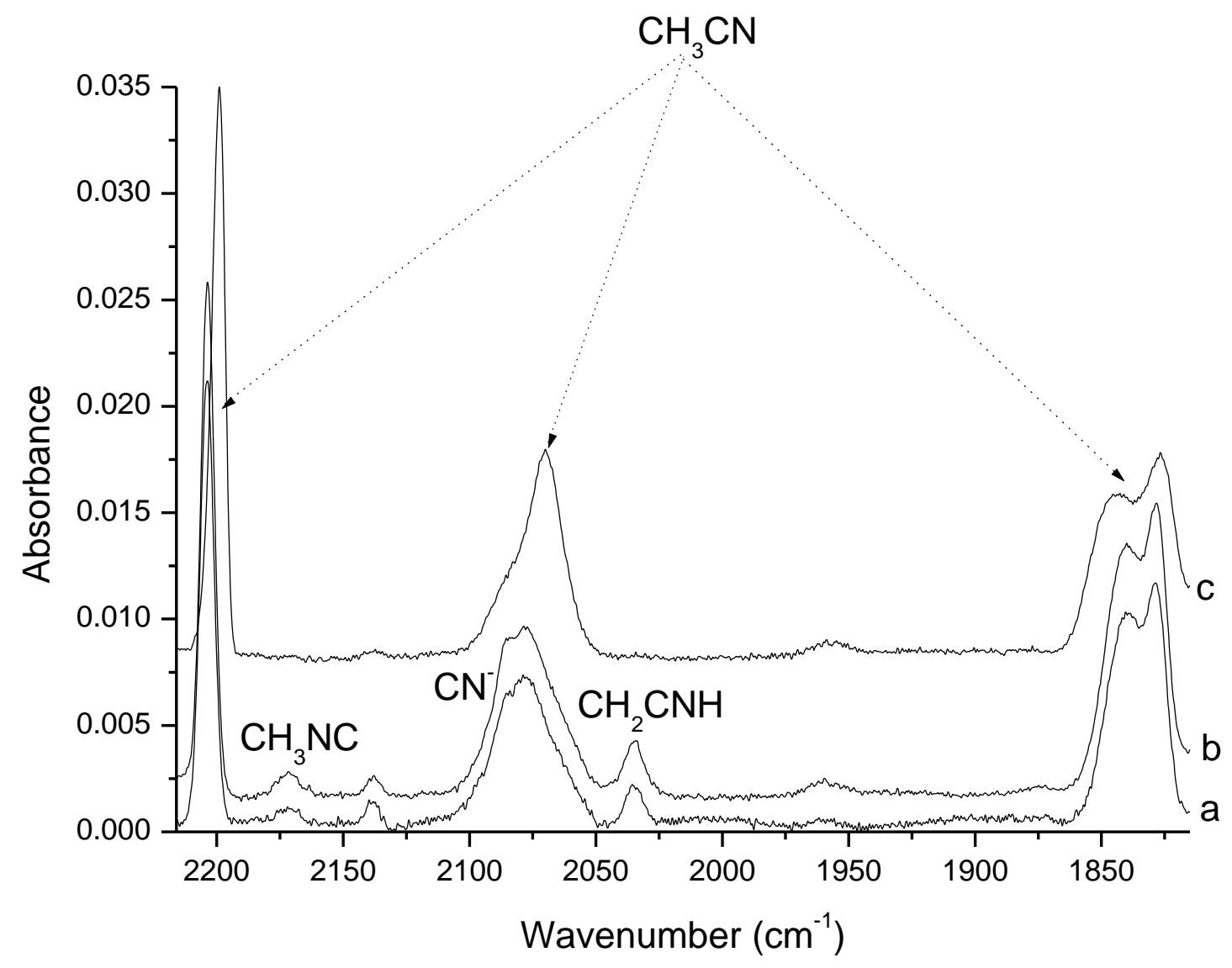

Figure 5: $\mathrm{CH}_{3} \mathrm{CN}+\mathrm{N} / \mathrm{N}_{2}$ co-deposition at a) $10 \mathrm{~K}$, b) $20 \mathrm{~K}$, c) $40 \mathrm{~K}$

As mentioned above, we have the possibility with our experimental setup to investigate icy samples formed though indirect deposition through simultaneous condensation of $\mathrm{CH}_{3} \mathrm{CN}+$ $\mathrm{N} / \mathrm{N}_{2}$ mixture gas suspended in the vacuum chamber. Spectra $6 \mathrm{a}$ and $6 \mathrm{~b}$ show the results of indirect deposition at $20 \mathrm{~K}$ of $\mathrm{CH}_{3} \mathrm{CN}+\mathrm{N}_{2}$ and $\mathrm{CH}_{3} \mathrm{CN}+\mathrm{N} / \mathrm{N}_{2}$, respectively. Although we observe the same IR signals as for a direct co-injection experiment but with very low intensity, there is a clear distinction between the signals due to the reactants and those due to the reaction products. 


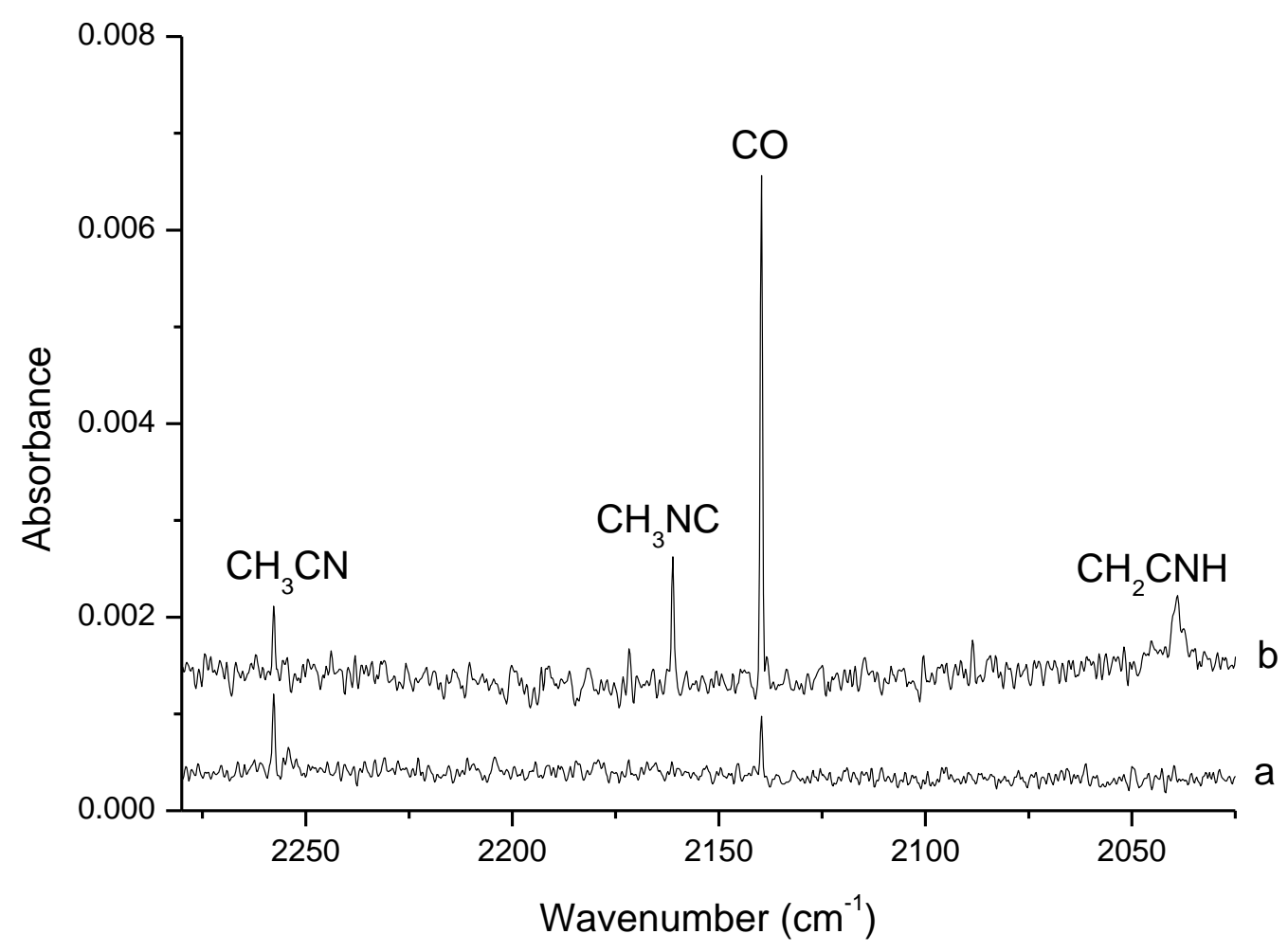

Figure 6: Simultaneous condensation at $20 \mathrm{~K}$ of mixture gas suspended in the vacuum chamber of a) $\mathrm{CH}_{3} \mathrm{CN}+\mathrm{N}_{2}$ b) $\mathrm{CH}_{3} \mathrm{CN}+\mathrm{N} / \mathrm{N}_{2}$. $\mathrm{CO}$ molecule is detected as an impurity.

We have calculated the integrated absorption areas of the $\mathrm{CN}$ absorption bands of $\mathrm{CH}_{3} \mathrm{CN}$, $\mathrm{CH}_{3} \mathrm{NC}$ and $\mathrm{CH}_{2} \mathrm{CNH}$, for direct (spectrum $1 \mathrm{~b}$ ) and indirect co-depositions (spectrum $6 \mathrm{~b}$ ). We found a set of $\left(9.70,0.013\right.$ and $\left.0.025 \mathrm{~cm}^{-1}\right)$ and $\left(0.001,0.002\right.$ and $\left.0.003 \mathrm{~cm}^{-1}\right)$ for the integrated absorption areas of $\left(\mathrm{CH}_{3} \mathrm{CN}, \mathrm{CH}_{3} \mathrm{NC}, \mathrm{CH}_{2} \mathrm{CNH}\right)$, respectively, with relative uncertainties ranged between 0.5 and $20 \%$. Knowing the band strengths ${ }^{25}$ of the $\mathrm{CN}$ absorption bands of $\mathrm{CH}_{3} \mathrm{CN}, \mathrm{CH}_{3} \mathrm{NC}$ and $\mathrm{CH}_{2} \mathrm{CNH}$ at 2255,2167 and $2038 \mathrm{~cm}^{-1}\left(2.2 \times 10^{-18}\right.$ cm molecule ${ }^{-1}$ for $\mathrm{CH}_{3} \mathrm{CN}, \mathrm{CH}_{3} \mathrm{NC}$ and $7.2 \times 10^{-17} \mathrm{~cm}$ molecule ${ }^{-1}$ for $\mathrm{CH}_{2} \mathrm{CNH}$ ) allows to have a concentration distribution between the three species for the two deposition methods. For the direct $\mathrm{CH}_{3} \mathrm{CN}+\mathrm{N} / \mathrm{N}_{2}$ co-deposition, we form a solid sample made of $4.4 \times 10^{18}$ molecule $\mathrm{cm}^{-2}$ of $\mathrm{CH}_{3} \mathrm{CN}$ mixed to $5.9 \times 10^{15}$ and $3.510^{14}$ molecule $\mathrm{cm}^{-2}$ of $\mathrm{CH}_{3} \mathrm{NC}$ and $\mathrm{CH}_{2} \mathrm{CNH}$, respectively. It is mainly a $\mathrm{CH}_{3} \mathrm{CN}$ ice containing $0.13 \%$ of $\mathrm{CH}_{3} \mathrm{NC}$ and $0.008 \%$ of $\mathrm{CH}_{2} \mathrm{CNH}$. While for the indirect co-deposition, even if the $\mathrm{CH}_{3} \mathrm{CN}$ is the primary reactant, the main species in the resulting solid sample is the reaction product $\mathrm{CH}_{3} \mathrm{NC}$, the less stable isomer of $\mathrm{CH}_{3} \mathrm{CN}$. In fact we measure $4.5 \times 10^{14}$ molecule $\mathrm{cm}^{-2}$ of $\mathrm{CH}_{3} \mathrm{CN}$ versus $9.0 \times 10^{14}$ and $4.2 \times 10^{13}$ molecule $\mathrm{cm}^{-2}$ of $\mathrm{CH}_{3} \mathrm{NC}$ and $\mathrm{CH}_{2} \mathrm{CNH}$, respectively. It is a mixed ice made of $64.6 \%$ of 
$\mathrm{CH}_{3} \mathrm{NC}, 32.3 \%$ of $\mathrm{CH}_{3} \mathrm{CN}$ and $3.1 \%$ of $\mathrm{CH}_{2} \mathrm{CNH}$. These two co-deposition methods give concentration ratios $\left[\mathrm{CH}_{3} \mathrm{CN}\right] /\left[\mathrm{CH}_{3} \mathrm{NC}\right] /\left[\mathrm{CH}_{2} \mathrm{CNH}\right]$ equal to $4400 / 5.9 / 0.4$ and 4.5/9.0/0.4 for the direct and indirect co-depositions, respectively. Table 1 sums up the column densities of the three isomers involved in $\mathrm{CH}_{3} \mathrm{CN}+\mathrm{N}$ reaction, for samples formed through direct and indirect $\mathrm{CH}_{3} \mathrm{CN}+\mathrm{N} / \mathrm{N}_{2}$ co-deposition at $20 \mathrm{~K}$.

Table 1: Column densities of $\mathrm{CH}_{3} \mathrm{CN}, \mathrm{CH}_{3} \mathrm{NC}$ and $\mathrm{CH}_{2} \mathrm{CNH}$ in interstellar ice analogues formed through direct and indirect $\mathrm{CH}_{3} \mathrm{CN}+\mathrm{N} / \mathrm{N}_{2}$ co-depositions at $20 \mathrm{~K}$.

\begin{tabular}{|c|c|c|}
\hline \multirow{2}{*}{ Molecule } & \multicolumn{2}{|c|}{ Column Density / molec cm ${ }^{-2}$} \\
\cline { 2 - 3 } & Direct deposition & Indirect deposition \\
\hline $\mathrm{CH}_{3} \mathrm{CN}$ & $4.4 \times 10^{18}$ & $4.5 \times 10^{14}$ \\
\hline $\mathrm{CH}_{3} \mathrm{NC}$ & $5.9 \times 10^{15}$ & $9.0 \times 10^{14}$ \\
\hline $\mathrm{H}_{2} \mathrm{CCNH}$ & $3.5 \times 10^{14}$ & $4.2 \times 10^{13}$ \\
\hline
\end{tabular}

Taking measurement uncertainties into account, we have measured $\left[\mathrm{CH}_{3} \mathrm{NC}\right] /\left[\mathrm{CH}_{2} \mathrm{CNH}\right]$ abundance ratios of $16.9 \pm 2.0$ and $21.4 \pm 4.3$ for the direct and indirect $\mathrm{CH}_{3} \mathrm{CN}+\mathrm{N} / \mathrm{N}_{2}$ codeposition carried out at $20 \mathrm{~K}$, respectively. As mentioned above this ratio has been estimated around $10.4 \pm 1.2$ for the direct co-deposition performed at $10 \mathrm{~K}$. The $\left[\mathrm{CH}_{3} \mathrm{NC}\right] /\left[\mathrm{CH}_{2} \mathrm{CNH}\right]$ ratio seems to depend not only in the temperature of the reactants co-deposition but also in the method of the formation of the solid sample, more precisely in how $\mathrm{CH}_{3} \mathrm{CN}, \mathrm{N}$ and $\mathrm{N}_{2}$ reach the mirror surface of the sampler to form the $\mathrm{CH}_{3} \mathrm{CN}$ containing ice.

We notice also that for a direct sample deposition, $\left[\mathrm{CH}_{3} \mathrm{NC}\right] /\left[\mathrm{CH}_{2} \mathrm{CNH}\right]$ abundance ratio increases with increasing the temperature of $\mathrm{CH}_{3} \mathrm{CN}+\mathrm{N} / \mathrm{N}_{2}$ co-deposition while it shows a behavior completely different during the heating of the sample from 10 to $40 \mathrm{~K}$. At $10 \mathrm{~K}$ just after the sample deposition $\mathrm{CH}_{3} \mathrm{NC}$ and $\mathrm{CH}_{2} \mathrm{CNH}$ have been formed with an $\left[\mathrm{CH}_{3} \mathrm{NC}\right] /\left[\mathrm{CH}_{2} \mathrm{CNH}\right]$ abundance of $10.4 \pm 1.2$ which decreases to $6.8 \pm 0.8$ with increasing the sample temperature. Consequently, the evolution of $\left[\mathrm{CH}_{3} \mathrm{NC}\right] /\left[\mathrm{CH}_{2} \mathrm{CNH}\right]$ abundance ratios versus temperature would inform in the mechanisms involved into $\mathrm{CH}_{3} \mathrm{NC}$ and $\mathrm{CH}_{2} \mathrm{CNH}$ formation from $\mathrm{CH}_{3} \mathrm{CN}+\mathrm{N}$ solid state reaction. By increasing the temperature of the reaction, high $\left[\mathrm{CH}_{3} \mathrm{NC}\right] /\left[\mathrm{CH}_{2} \mathrm{CNH}\right]$ ratios would be obtained for $\mathrm{CH}_{3} \mathrm{CN}+\mathrm{N}$ reaction occurring at the interface solid-gas while low ratios are found for reactions taking place 
exclusively in solid phase. In fact, during the sample deposition, the $\mathrm{CH}_{3} \mathrm{CN}+\mathrm{N}$ reaction combines processes from solid phase, surface and interface solid-gas. While during the heating from 10 to $40 \mathrm{~K}$, of the sample formed at $10 \mathrm{~K}$ the $\mathrm{CH}_{3} \mathrm{CN}+\mathrm{N}$ reaction occurs only in solid phase, leading to a decrease of $\left[\mathrm{CH}_{3} \mathrm{NC}\right] /\left[\mathrm{CH}_{2} \mathrm{CNH}\right]$ abundance ratio from $10.4 \pm 1.2$ to $6.8 \pm 0.8$, showing that at high temperatures the most stable isomer is favored against the less stable one while at low temperatures the reverse occurs. Such a behavior is similar to that of the $[\mathrm{HNC}] /[\mathrm{HCN}]$ abundance ratio $^{27}$ which also shows a decrease with increasing temperature in star forming regions. In fact, the less stable isomer $\mathrm{HNC}$ is found ${ }^{28}$ about 60.3 $\mathrm{kJ} / \mathrm{mol}$ above $\mathrm{HCN}$ while $\mathrm{CH}_{3} \mathrm{NC}$ is only $6 \mathrm{~kJ} / \mathrm{mol}$ above ${ }^{8} \mathrm{CH}_{2} \mathrm{CNH}$. However in both cases, the mounts of the higher energy isomer seem to decrease with rising the temperature. Similarly in the case of HNCO metastable isomers, HOCN and HCNO which have been detected in several sources of prestellar cores and low-mass protostellar ${ }^{29}$ objects the amount of HCNO isomer which is higher ${ }^{30}$ in energy by $192 \mathrm{~kJ} / \mathrm{mol}$ than HOCN seems to be depleted in molecular clouds when the temperature increases. In order to explain the behavior of $[\mathrm{HCNO}] /[\mathrm{HOCN}]$ abundance ratio of the two metastable isomers of HNCO versus temperature and why the less stable isomer HCNO is under-abundant with respect to HOCN in the warm sources but not in the cold ones, Schuurman et al. suggest that it would be due either the mechanism that converts $\mathrm{HCNO}$ into $\mathrm{HOCN}$, in comparison ${ }^{27}$ with the conversion of $\mathrm{HNC}$ into $\mathrm{HCN}$ in warm sources, or the solid state chemistry on interstellar grains which may play a key role in the relative abundances of $[\mathrm{HCNO}] /[\mathrm{HOCN}]$. The detection towards Sagittarius B2(N) hot cores of $\mathrm{CH}_{3} \mathrm{CN}, \mathrm{CH}_{3} \mathrm{NC}$ and $\mathrm{CH}_{2} \mathrm{CNH}$ with $\left[\mathrm{CH}_{3} \mathrm{CN}\right] /\left[\mathrm{CH}_{3} \mathrm{NC}\right]$ and $\left[\mathrm{CH}_{3} \mathrm{CN}\right] /\left[\mathrm{CH}_{2} \mathrm{CNH}\right]$ ratios approximately equal to 30 and 100 , respectively, would suggest that the $\left[\mathrm{CH}_{3} \mathrm{NC}\right] /\left[\mathrm{CH}_{2} \mathrm{CNH}\right]$ abundance ratio should be around 7 which is the same order of magnitude as the one we obtain experimentally for $\mathrm{CH}_{3} \mathrm{CN}+\mathrm{N}$ reaction when the temperature increases from 10 to $40 \mathrm{~K}$. While in previous studies involving energetic processing of solid $\mathrm{CH}_{3} \mathrm{CN}$, Hudson ${ }^{25}$ et al. showed that $\mathrm{UV}$ photolysis and proton irradiation of $\mathrm{CH}_{3} \mathrm{CN}$ ices lead to the formation of $\mathrm{CH}_{3} \mathrm{NC}$ and $\mathrm{CH}_{2} \mathrm{CNH}$ with $\left[\mathrm{CH}_{3} \mathrm{NC}\right] /\left[\mathrm{CH}_{2} \mathrm{CNH}\right]$ abundance ratios equal to 1.7 and 0.3 , respectively. The $\left[\mathrm{CH}_{3} \mathrm{NC}\right] /\left[\mathrm{CH}_{2} \mathrm{CNH}\right]$ ratios derived from UV photolysis and proton irradiation of $\mathrm{CH}_{3} \mathrm{CN}$ ices are much lower than those reported from astronomical observations or those obtained through $\mathrm{CH}_{3} \mathrm{CN}+\mathrm{N}$ solid state reactions. The present study suggests that $\mathrm{CH}_{3} \mathrm{NC}$ and $\mathrm{CH}_{2} \mathrm{CNH}$ would form in cold molecular regions of star forming regions where $\mathrm{CH}_{3} \mathrm{CN}$ and nitrogen atoms may be trapped in the icy interstellar grains. $\mathrm{CH}_{3} \mathrm{NC}$ and $\mathrm{CH}_{2} \mathrm{CNH}$ would form in solid phase through $\mathrm{CH}_{3} \mathrm{CN}+\mathrm{N}$ solid state reaction at temperatures lower than $40 \mathrm{~K}$ before desorbing in the gas phase. The analysis 
$\left[\mathrm{CH}_{3} \mathrm{NC}\right] /\left[\mathrm{CH}_{2} \mathrm{CNH}\right]$ ratios and their behaviors versus temperature would then permit to access to synthesis routes of $\mathrm{CH}_{3} \mathrm{NC}$ and $\mathrm{CH}_{2} \mathrm{CNH}$ form $\mathrm{CH}_{3} \mathrm{CN}$ as precursor in the ISM.

\section{CONCLUSIONS}

We show by varying the reaction temperature between 10 and $40 \mathrm{~K}$ that $\mathrm{CH}_{3} \mathrm{CN}+\mathrm{N}$ is efficient in solid phase in a very specific temperature range, leading to the formation of $\mathrm{CH}_{3} \mathrm{NC}$ and $\mathrm{CH}_{2} \mathrm{CNH}$ with $\left[\mathrm{CH}_{3} \mathrm{NC}\right] /\left[\mathrm{H}_{2} \mathrm{C}=\mathrm{C}=\mathrm{NH}\right]$ abundance ratios which depend in the temperature of the reaction and also in the environments where the reactants are trapped. To be efficient, the temperature domain of the $\mathrm{CH}_{3} \mathrm{CN}+\mathrm{N}$ reaction must combine long surface residence time and high mobility of $\mathrm{N}$ atoms to allow the $\mathrm{N}\left({ }^{4} \mathrm{~S}\right)-\mathrm{N}\left({ }^{4} \mathrm{~S}\right)$ recombination and the formation of the long lived metastable species $\mathrm{N}_{2}(\mathrm{~A})$ which induces through energy transfer process the $\mathrm{CH}_{3} \mathrm{CN}$ isomerization. Additionally, in order to change the environment where the three isomers involve, we have investigated two different methods of synthesis of our interstellar ice analogues containing $\mathrm{CH}_{3} \mathrm{CN}$ and $\mathrm{N}$ as precursors. The first method is a traditional one, adopted by many groups studying molecule + atom/radical solid phase reactions, which consists on the co-deposition of the reactants on a surface of a cryogenic mirror located front of the reactants injection ports. The second method we have applied is to form the solid samples through an instantaneous condensation of the mixture gas suspended in the vacuum chamber on a cryogenic mirror. These two experimental methods are used simultaneously to give two different interstellar ice analogues under the same experimental conditions, however, we have managed with the latter method to get solid samples containing more reaction products than reactants which impacts the $\left[\mathrm{CH}_{3} \mathrm{CN}\right] /\left[\mathrm{H}_{2} \mathrm{C}=\mathrm{C}=\mathrm{NH}\right] /\left[\mathrm{CH}_{3} \mathrm{NC}\right]$ abundance ratios. We have observed a decrease of $\left[\mathrm{CH}_{3} \mathrm{NC}\right] /\left[\mathrm{CH}_{2} \mathrm{CNH}\right]$ abundance ratio by increasing the temperature of $\mathrm{CH}_{3} \mathrm{CN}+\mathrm{N}$ reaction, showing that at high temperatures the most stable isomer is favored against less stable one. Such a behavior is similar to those of the $[\mathrm{HNC}] /[\mathrm{HCN}]$ and $[\mathrm{HCNO}] /[\mathrm{HOCN}]$ abundance ratios which also shows a decrease with increasing temperature in molecular clouds.

\section{ACKNOWLEDGMENT}

This work was supported in part by the CNRS program "Physique et Chimie du Milieu Interstellaire" (PCMI) and the LabEx MiChem "French state funds managed by the ANR within the Investissements d'Avenir programme under reference ANR-11-IDEX-0004-02." 


\section{REFERENCES}

(1) Solomon, P. M.; Jefferts, K. B.; Penzias, A. A.; Wilson, R. W. Detection of millimeter emission lines from interstellar methyl cyanide. Astrophys. J. 1971, 168, L107-L110.

(2) Gerin, M.; Combes, F.; Wlodarczak, G.; Jacq, T.; Guelin, M.; Encrenaz, P.; Laurent, C. Interstellar detection of deuterated methyl cyanide. A\&A. 1992, 259, L35-L38.

(3) Belloche, A.; Müller, H. S. P.; Garrod, R. T.; Menten, K. M. Exploring molecular complexity with ALMA (EMoCA): Deuterated complex organic molecules in Sagittarius B2(N2). 2016, $A \& A$, 587, A91

(4) Cernicharo, J.; Kahane, C.; Guelin, M.; Gomez-Gonzalez, J. Tentative detection of $\mathrm{CH}_{3} \mathrm{NC}$ towards SGR B2. A\&A. 1988, 189, L1-L2.

(5) Remijan, A. J.; Hollis, J. M.; Lovas, F. J.; Plusquellic, D. F.; Jewell, P. R. Interstellar Isomers: The importance of bonding energy differences. Astrophys. J. 2005, 632, 333-339.

(6) Calcutt, H.; Fiechter, M. R.; Willis, E. R. ; Müller, H. S. P. ; Garrod, R. T.; Jørgensen, J. K.; Wampfler, S. F.; Bourke, T. L.; Coutens, A.; Drozdovskaya, M. N.; Ligterink, N. F. W.; Kristensen, L. E. The ALMA-PILS survey: first detection of methyl isocyanide $\left(\mathrm{CH}_{3} \mathrm{NC}\right)$ in a solar-type protostar. $A \& A$. 2018, 617, A95.

(7) Lovas, F. J.; Hollis, J. M.; Remijan, A. R.; Jewell, P. R. Detection of ketenimine $\left(\mathrm{CH}_{2} \mathrm{CNH}\right)$ in Sagittarius B2(N) hot cores. Astrophys. J. 2006, 645, L137-140.

(8) Cho, H. G. Matrix infrared spectra and DFT computations of $\mathrm{CH}_{2} \mathrm{CNH}$ and $\mathrm{CH}_{2} \mathrm{NCH}$ produced from $\mathrm{CH}_{3} \mathrm{CN}$ by Laser-ablation plume radiation. Bull. Korean Chem. Soc. 2013, 34 , 1361-1365.

(9) Ulich, B. L.; Conklin, E. K. Detection of methyl cyanide in Comet Kohoutek. Nature. 1974, 248. 121-122.

(10) Irvine, W.; Friberg, P.; Hjalmarson, A.; Ishikawa, S.; Kaifu, N.; Kawaguchi, K.; Madden, S. C.; Mathews, H. E.; Ohishi, M.; Saito, S.; Suzuki, H.; Thaddeus, P.; Turner, B. E.; Yamamoto, S.; Ziurys, L. M. Identification of the interstellar cyanomethyl radical $\left(\mathrm{CH}_{2} \mathrm{CN}\right)$ in the molecular clouds TMC-1 and Sagittarius B2(N). Astrophys. J. 1988, 334, L107-L111.

(11) Habing, R.J; MacDonald, G. H. Methyl cyanide in Orion-KL. A\&A, 1991, 52, 705-711.

(12) Wilner, D. J.; Wrigth, M. C.; Planbeck, R. Maps of $92 \mathrm{GHz}$ methyl cyanide emission in Orion-KL. Astrophys. J. 1994, 422, 642-651.

(13) A’Hearn, M.F.; Belton, M.J.S.; Delamere, W.A.; Kissel, J.; Klaasen, K.P.; McFadden, L.A.; Meech, K. J.; Melosh, H. J.; Schultz, P. H.; Sunshine, J. M.; Thomas, P. C.; Veverka, J.; Yeomans, D. K.; Baca, M. W.; Busko I.; Crockett, C.J.; Collins S. M.; Desnoyer, M.; Eberhardy, C. A.; Ernst, C. M.; Farnham, T. L.; Feaga, L.; Groussin, O.; Hampton, D.; Ipatov, 
S. I.; Li, J. -Y.; Lindler, D.; Lisse, C. M.; Mastrodemos, N.; Owen, Jr. W. M.; Richardson, J. E.; Wellnitz, D. D. Deep impact: excavating comet Tempel 1. Science. 2005, 310, 258-264.

(14) Remijan, A. J.; Milam, S. N.; Womack, M.; Apponi, A. J.; Ziurys, L. M.; Wyckoff, S.; A'Hearn, M. F.; Pater, I. de.; Forster, J. R.; Friedel, D. N.; Palmer, P.; Snyder, L. E.; Veal, J. M.; Woodney, L. M.; Wright, M. C. H. The distribution, excitation, and formation of cometary molecules: Methanol, methyl cyanide, and ethylene glycol, Astrophys. J. 2008, 689, 613-621.

(15) Paubert, G.; Gautier, D.; Courtin, R. The millimeter spectrum of Titan: Detectability of $\mathrm{HCN}, \mathrm{HC}_{3} \mathrm{~N}$, and $\mathrm{CH}_{3} \mathrm{CN}$ and the $\mathrm{CO}$ abundance. Icarus. 1984, 60, 599-612.

(16) Hudson, R.L.; Moore, M.H.; Dworkin, J.P.; Martin, M.P.; Pozun, Z.D. Amino acids from ion-irradiated nitrile-containing ices. Astrobio. 2008, 8, 771-779.

(17) Abdulgalil, A.G.; Marchione, D.; Thrower, J.D.; Collings, M.P.; McCoustra, M.R.S.; Islam, F.; Palumbo, M.E.; Congiu, E.; Dulieu, F. Laboratory studies of electron and ion irradiation of solid acetonitrile $\left(\mathrm{CH}_{3} \mathrm{CN}\right)$. Philos. Trans. R. Soc. A. 2013, 371, 1-20.

(18) Mencos, A.; Krim L. Isomerization and fragmentation of acetonitrile upon interaction with $\mathrm{N}\left({ }^{4} \mathrm{~S}\right)$ atoms: the chemistry of nitrogen in dense molecular clouds. MNRAS. 2016, 460, 1990-1998.

(19) Schriver, L.; Schriver, A.; Perchard, J-P. Infrared matrix-isolation study of the molecular complexes between acetonitrile and hydrogen halides. J. Chem. Soc., Faraday Trans. 1985, $81,1407-1425$.

(20) Pravilov, A.M.; Smirnova , L.G.; Vilesov, A.F. Kinetics photorecombination of N $\left({ }^{4} S\right)$ atoms: Vegard-Kaplan bands. Chem. Phys. Lett. 1984, 109, 343-346.

(21) Guerra, V.; Sa, P.A.; Loureiro, J. Role played by the $\mathrm{N}_{2}\left(\mathrm{~A}^{3} \Sigma_{\mathrm{u}}{ }^{+}\right)$metastable in stationary $\mathrm{N}_{2}$ and $\mathrm{N}_{2}-\mathrm{O}_{2}$ discharges. J. Phys. D: Appl. Phys. 2001, 34, 1745-1755.

(22) Pan, S.L.; Zumofen, G.; Dressler, K. Vibrational relaxation in the $\mathrm{A}^{3} \Sigma_{\mathrm{u}}$ state of $\mathrm{N}_{2}$ in rare gas matrices. J. Chem. Phys.1987, 87, 3482-3491.

(23) Guerra,V.; Tatarova, E.; Ferreira, C.M. Kinetics of metastable atoms and molecules in $\mathrm{N}_{2}$ microwave discharges. Vacuum. 2002, 69,171-176.

(24) Amicangelo, J. C.; Collier, J. R.; Dine, C. T.; Saxton, N. L.; Schleicher, R. M. Matrix isolation infrared observation of $\mathrm{N}_{3}$ using a nitrogen microwave discharge plasma source. Mol. Phys. 2007, 105, 989-1002.

(25) Hudson, R. L.; Moore M. H. Reactions of nitriles in ices relevant to Titan, comets, and the interstellar medium: formation of cyanate ion, ketenimines, and isonitriles. Icarus. 2004, $172,466-478$.

(26) Bisschop, S.E.; Fraser, H.J.; Öberg, K.I.; vanDishoeck, E.F.; Schlemmer, S. Desorption rates and sticking coefficients for $\mathrm{CO}$ and $\mathrm{N}_{2}$ interstellar ices. A\&A. 2006, 449, 1297-1309. 
(27) Graninger, D.M.; Herbst, E.; Öberg, K.I.; Vasyunin, A. I. The HNC/HCN ratio in starforming regions. Astrophys. J. 2014, 787, 1-11.

(28) Lee, T.J. ; Rendell, A.P. The structure and energetic of the $\mathrm{HCN} \rightarrow \mathrm{HNC}$ transition. Chem. Phys. Lett. 1991,177, 491-497.

(29) Marcelino, N.; Brünken, S.; Cernicharo, J.; Quan, D.; Roueff, E.; Herbst, E.; Thaddeus, P. The puzzling behavior of HNCO isomers in molecular clouds. A\&A. 2010, 516, A105.

(30) Schuurman, M. S.; Muir, S. R.; Allen, W. D.; Shaefer, H. F. Toward subchemical accuracy in computational thermochemistry: focal point analysis of the heat of formation of NCO and [H,N,C,O] isomers. J. Chem. Phys. 2004, 120, 11586-11599 